\title{
Systems Thinking, Gender, and Sex
}

\section{Josephine Maxima Acosta-Pasrischa†}

\begin{abstract}
This is an academic paper formally presented twice in Asian Philosophical Conferences and many times as a call to action in universities in Asia and the US. It is recently rethought and reframed, reinvented and reengineered through Systems Thinking, suggested for use by philosophy professors teaching feminism, gender studies and women studies. It surveys the outcomes of the Millennium Development Goals of 2000-2015 by the present author as a witness and participant in conferences and movements. The author brings into Presence and Presencing the momentous achievements of the "Empowerment of Women and the Girl Child." It is now especially relevant with the establishment of UN Women, the UN Entity for gender equality and empowerment of women and girls on January 2011; the Millennium Development Goals 2000-2015; and Sustainable Development Goals 2015-2030. Michelle Bachelet, president of Chile 2006-2010, and then again for another term 2014-2018, a doctor of medicine, defense specialist and divorced/single mother of three children, is the first UN Women head, appointed as undersecretary general of the United Nations on 15 September 2010. Phumzile Miambo-Ngcuka is the current executive director of UN Women since 19 August 2013.
\end{abstract}

Keywords: systems thinking, United Nations Millennium Development Goals of 2000-2015, gender, women empowerment

\section{Historical Context}

7 The Millennium Summit, which came out with the Millennium Development Goals in 2000, has celebrated its $10^{\text {th }}$ anniversary on 20 22 September 2010 at the United Nations in New York. The heads of state/government and the representatives of 192 countries attended and assessed what their countries have done in ten years and what they still have to do for the next five to ten years.

(C) 2020 Josephine Maxima Acosta-Pasricha

https://www.kritike.org/journal/issue 26/pasricha june2020.pdf

ISSN 1908-7330 
US President Barack Obama said in 2009: “We will support the Millennium Development Goals and approach next year's summit with a Global Plan to make them a reality and set our own sights to the eradication of extreme poverty in our time." At the United Nations in 2010, President Obama presented a New US Global Development Policy that is founded on three criteria of winner countries-good governance, economic stability, and results/outcomes. This shows a very strategic leadership because it is "soft power" in action - the ability to set and attain goals without the use of force. Then UN Secretary-General Ban Ki-moon also distributed "A Global Strategy for Women's and Children's Health," a strategic handbook that contains policies, processes, programs, best practices and actions to help countries cut maternal mortality and infant mortality by two thirds by 2015 . Policies are rules for selecting any means towards a goal or defining function. Processes are sequences of actions directed to goals. Programs are combinations of actions directed to a particular goal. Practices are repeated actions. Actions are one-time choices of means. ${ }^{1}$

"Stand up, take action and make noise for the MDGs" also happened around the world on 17-19 September 2010. So "Wake me up when the data is over." 2

Feminists got waken up when the Millennium Document 2010 got signed, which promised US \$26 Billion for maternal and infant health care for 2011 alone, and US $\$ 40$ Billion for the next five years to the Global Fund. Then, women could do Data Story-Telling with MDG road warriors on the ground. Women could do "Storyfying" (defined as to narrate or to describe in a story) the experiences of women, especially rural women, at the UN Commission of the Status of Women. It is People Power People ${ }^{3}$ in action, a trend started by icon Corazon Aquino for change management and transformational leadership. Rio+20 followed in June 2012.

The Commission on the Status of Women and member states met on 27 February to 9 March 2012 at the United Nations in New York to pave the way for joining Rio+20 on Sustainable Development. The present author submitted her paper on "Teaching/Learning Gender and Sex Through Systems Thinking in Asia and Africa" ${ }^{4}$ to the pool of Rio+20 in Rio de Janeiro,

\footnotetext{
${ }^{1}$ See Russell Ackoff, Herbert J. Addison, and Sally Bibb, A Little Book of f-Laws: 13 Common Sins of Management (Devon, UK: Triarchy Press, 2006).

${ }^{2}$ Lori L. Silverman, Wake Me Up When the Data is Over: How Organizations Use Stories to Drive Results (USA: John Wiley \& Sons, 2006).

${ }^{3}$ Corazon Aquino, in 1986, originated the idea of People Power during her presidential campaign and subsequent People Power Revolution.

${ }^{4}$ Josephine Acosta-Pasricha, "Teaching/Learning Gender and Sex Through Systems Thinking in Asia and Africa" (paper presented at the Rio+20: United Nations Conference on Sustainable Development, Rio de Janeiro, Brazil, 20-22 June 2012).

(c) 2020 Josephine Maxima Acosta-Pasricha https://www.kritike.org/journal/issue 26/pasricha june2020.pdf ISSN 1908-7330

(c) BY-NC-ND
} 
Brazil meeting on 20-22 June 2012. The author joined the debates and discussions on the creation of seventeen Sustainable Development Goals.

UN Women Director Michelle Bachelet called for women's equal participation in all spheres of life as fundamental to democracy and justice. Countries with higher gender equality enjoy higher level of growth, she said. Ban Ki-moon said that equality for women and girls is not only a basic human right; it is a social and economic imperative.

A corollary to the themes is the stand of Ban Ki-moon with gay, lesbian, bisexual and transgender people, calling on all countries to join him. Any attack on LGBT people is an attack on universal values; the rights of LGBT is part of human rights, Ban Ki-moon says. ${ }^{5}$

\section{Introduction}

The metaphor here of Systems Thinking is when a leaf* in the Himalaya ranges flaps its wings, like a butterfly in the Amazon jungle, it can conceivably lead to storms in the South China Sea.

A System, according to Russell Ackoff, is defined as

A set of interrelated elements. Thus, a system is an entity which is composed of at least two elements and a relation that holds between each of its elements and at least one other elements in the set. Each of a system's elements is connected to every other element, directly or indirectly. Furthermore, no subset of elements is unrelated to any other subset. ${ }^{6}$

It implies two foundations: ${ }^{7}$ (1) a Whole contains two or more parts, each of which can affect the properties or behavior of the Whole; (2) None of the properties has an independent effect on the Whole because parts are all interconnected.

\footnotetext{
* Editors' Note: The author was perhaps alluding to the butterfly effect when she described the flapping of leaves in the Himalayas.

${ }^{5}$ United Nations, "Ban calls for efforts to secure equal rights for LGBT community," in United Nations Sustainable Development Goals (21 September 2016), <https://www.un.org/ sustainabledevelopment/blog/2016/09/ban-calls-for-efforts-to-secure-equal-rights-for-lgbtcommunity/>.

${ }^{6}$ Russell Ackoff, “Towards a System of Systems Concept," in Management Science, 17:11 (July 1971), 662. See also Russell Ackoff, "Systems Thinking Speech by Dr. Russell Ackoff," Awal Street Journal in YouTube (1 November 2015), <https://www.youtube.com/ watch?v=EbLh7rZ3rhU>.

${ }^{7}$ Ackoff, "Systems Thinking Speech."
} 


\section{SYSTEMS THINKING, GENDER, AND SEX}

The Butterfly Effect in Systems Thinking means that "the flapping of a butterfly wing in Brazil could stir the air that causes chain reaction of greater and greater proportions, and ultimately results in a raging storm over Europe." 8 It means that a simple thing, like a royal wedding or the first overseas trip to Canada and the United States of a royal couple like Prince William and Catherine, Duke and Duchess of Cambridge, or Prince Harry and Megan, Duke and Duchess of Sussex can have chain reactions of bigger and greater proportions. Another example of the Butterfly Effect is how then Liberian President Ellen Johnson Sirleaf, Liberian peace activist Leymah Gbowee, and Yemeni human rights activist and journalist Tawakkul Karman-three outstanding women from Africa and the Middle East won the 2011 Nobel Peace Prize, and then have great chain reactions of big and great proportions for all women in Africa and the world.

Then US Secretary of State Hillary Clinton in her visit to Busan, Korea to attend the Fourth High Level Forum on Aid Effectiveness, said that nations which invest in women's employment, health, and education tend to have more economic growth. She suggested that countries put women at the center of development efforts. Clinton then proceeded to visit Myanmar and meet Aung San Suu Kyi, pro-democracy icon.

The Commission of the Status of Women also met along with member states on 27 February to 9 March 2012 at the United Nations.

The themes are well focused:

- Prong 1: empowerment of rural women to eradicate hunger and poverty.

- Prong 2: financing for the empowerment of women.

- Prong 3: education of men and women, boys and girls.

Events can have great impact on the environmental, economic, and geopolitical systems. Hopefully, such events can be life-giving to the youth, to women and girls, to the marginalized, deprived and disabled. The metaphor of conversation here between them and the world is also a rich image to understand the complexity of the human person, human systems, and complex adaptive systems that can unite and differentiate countries and peoples. It has great potential for discourse democracy and peace. ${ }^{9}$

\footnotetext{
${ }^{8}$ Daryl Conner, Leading at the Edge of Chaos: How to Create the Nimble Organization (New York: John Wiley \& Sons, 1998), 22.

9 See Michael Cavanaugh, "Coaching from a Systemic Perspective: A Complex Adaptive Conversation," in Evidence Based Coaching Handbook: Putting Best Practices to Work for your Clients, ed. by Dianne R. Stober and Anthony M. Grant (New Jersey: John Wiley \& Sons, 2006), 313-354.
}

(c) 2020 Josephine Maxima Acosta-Pasricha https://www.kritike.org/journal/issue 26/pasricha june2020.pdf ISSN 1908-7330

(cc) BY-NC-ND 


\section{Statement of the Problem}

The problem of this paper is how philosophy can promote gender equality and empowerment of girls and women-as mandated by the Millennium Development Goals 2000-2015 (MDGs) of the United Nations and seconded by the Sustainable Development Goals 2015-2030 - through Systems Thinking. The paper does not do "philosophy by justification" but "philosophy by praxis;" because it is role-modeling and praxis that is more effective for change management and behavior modification of masses of people in the field.

\section{Systems Thinking}

Since the 1950s up to today, Systems Thinking has found out that analysis, statistics, data, PowerPoint presentations of goals and outcomes are excellent for international and national policy makers and global fund donors; but they do not generally touch and change people on the ground. Quantitative fragmentation impacts on Intellectual Capital and Systems Optimization but at the expense of Public Mobilization. For example, the different definitions of extreme poverty or acute poverty in different countries also muddle the conversation and confuse the dialogue.

The 1968-1981 World Bank president, Robert McNamara, brought the discipline of Systems Analysis or process analysis and the term "absolute poverty" into public discourse in his famous Nairobi speech of 1973, where he suggested the two-pronged twin objectives of economic growth and poverty alleviation. What is poverty? McNamara says: "This is absolute poverty - a condition of life so limited as to prevent realization of the potential of the genes with which one is born, a condition of life so degrading as to insult human dignity, and yet a condition of life so common as to be the lot of some $40 \%$ of the peoples of developing countries." 10

Can Structures move 1.2 billion poor people in $2000,70 \%$ of which are women, from the poverty level of living on US \$1 a day, up to the first rung of the ladder of the lower middle class by 2015? According to the World Bank, for the year 2005, there are 1.4 billion people or one quarter of the population of the developing world, who live below the poverty line of US $\$ 1.25$ a day based on 2005 prices. ${ }^{11}$

${ }^{10}$ Robert S. McNamara, "Address to the Board of Governors," (address delivered to the Board of Governors of the World Bank at the Annual General Meeting, Nairobi, Kenya, 24 September 1973), <http://documents1.worldbank.org/curated/en/930801468315304694/ pdf/Address-to-the-Board-of-Governors-by-Robert-S-McNamara.pdf $>, 7$.

11 "Purchasing Power Parity 2005," in World Health Organization, $<$ https://www.who.int/choice/costs/ppp/en/>.

(c) 2020 Josephine Maxima Acosta-Pasricha

https://www.kritike.org/journal/issue 26/pasricha june2020.pdf

ISSN 1908-7330

(cc) BY-NC-ND 
According to the UNDP, for the year 2010, there are 1.7 billion people who live in acute poverty, with the new definition of poverty based on the Multidimensional Poverty Index (MPI), as developed by the Oxford Poverty and Human Development Initiative (OPDI). The MPI assesses a range of critical factors or "deprivations" at the household level-from education to health outcomes, assets, and key sources like water, sanitation, and electricity. As of June 2010, human population of the world is estimated at 6.82 billion. In 2009, the UN has estimated the Earth's human population to be 6.8 billion. In 2009, China has already moved 300 million poor to the middle class (that is equal to the entire total population of 300 million Americans in the US). In 2015, human population is 7.2 billion, while in the US current census bureau world population estimate in June 2019 of the global population is 7.5 billion. The current world population as of 2020 is $7,734,770,873$. So, would it take more than 15 to 25 years to move 1.4 billion poor people in the world up the ladder of human dignity, equality and "capabilities"?

Jeffrey Sachs, UN special adviser on the Millennium Development Goals, and director of Earth Institute at the Columbia University, says it is doable, practical and measurable, even monitorable and auditable. Through straightforward Systems, increasing efficiencies can be monitored by timelines, milestones, bottom-lines. Sachs says that the lack of financing for the MDGs has nothing to do with recession; it is caused by long-standing neglect. It is a political problem. There is a need for a New Aid Architecture, a new funding mechanism, a new window for funding in straightforward Design Systems. For example, the financing gap for MDG 5 (or maternal death in child birth and neonatal death of infants in the first 28 days of life) is US $\$ 35$ Billion - a mere $1 / 10$ of $1 \%$ of US $\$ 35$ Trillion, which is the annual income of the developed world. The Millennium Document of 2010 promises US \$26 Billion for the year 2011 alone, and US \$40 Billion for the next five years to the Global Fund.

Ban Ki-moon stated that global poverty is expected to decline by $15 \%$ by 2015 . There is a significant decrease of poverty noted in Asia. But there will still be 920 million people living below the poverty level, with hunger and malnourishment rising in South Asia. Progress is noted in the Sub Saharan Africa for access to primary education; progress in child health and gender equality in Latin America and the Caribbean. And there was that handbook of policies aimed at cutting maternal and infant mortality that Ban Ki-moon has distributed. ${ }^{12}$ But has anybody in government ever read it or even put them into action?

\footnotetext{
${ }^{12}$ See United Nations, "General Strategy for Women's and Children's Health," in Every Woman and Child, <http://www.everywomaneverychild.org/images/content/files/ global_strategy/full/20100914_gswch_en.pdf $>$.

(c) 2020 Josephine Maxima Acosta-Pasricha https://www.kritike.org/journal/issue 26/pasricha june2020.pdf ISSN 1908-7330
}

(c) BY-NC-ND 
The world's highest number of unemployed is also on record, with 211 million people unemployed, and a need for 470 million new jobs in the next 10 years to keep pace. Ban Ki-moon says that the financial crisis, food crisis and fuel crisis have impacted on the MDGs, so there is a need for midcourse corrections to accelerate progress, and to open windows of funding up to 2015. Ban Ki-moon has announced the formation of an Outside Panel of government officials and civic leaders as advocacy group for the MDGs with Rwandan President Paul Kagane, and Spanish Prime Minister Jose Luis Rodriguez Zapatero as co-chairs. Among the members of the panel are: Nobel Laureates Mohammad Yunus and Wangari Maathai, former Chilean president Michelle Bachelet, Graca Machel, Wang Yingfan, Stine Bosse, Philippe Douste-Blazy, Mukesh Ambani, Hiromasa Yonekura, Dho YoungShim, Julio Frenk, Akin Adisina, HHS Sheikha Mozah Bint Nasser, Jan Eliasson, Bob Geldof, Ray Chanders, Bill Gates, Ted Turner and Jeffrey Sachs. Perhaps, countries and local villages could also organize an Outside Panel of government leaders, civic actionists and social activists, as advocacy group to track foreign financial aid and delivery on the ground of the MDGs and eventually the SDGs. The Outside Panel can be composed of an executive director, secretary-general, eight advocates, each of whom is a specialist on one MDG or one or more SDG. How government narrows its gap with the people and involve the people in goals and actions is the "magic bullet" here-Systems Thinking that can move forward to the seventeen Sustainable Development Goals.

People Power, People!

\section{Outcomes of MDGs}

In September 2000, the Millennium Summit was the largest gathering of world leaders at the United Nations, participated in by 150 heads of State or heads of Governments. The Millennium Summit addressed major global challenges, in an agenda for reducing poverty, its causes and manifestations. The Millennium Summit came out with the Millennium Development Goals (MDGs) - or global targets that the leaders of the world set in the Millennium Declaration, such as: how to pull 1.2 billion people in 2000 out of extreme poverty, how to reverse the spread of HIV/AIDS, and how to protect the environment.

The most well-known target of the Millennium Declaration is the pledge to cut the number of people living in absolute poverty, which according to the United Nations definition of the term, poverty are people

(c) 2020 Josephine Maxima Acosta-Pasricha

https://www.kritike.org/journal/issue 26/pasricha june2020.pdf

ISSN 1908-7330

(cc) BY-NC-ND 
living on less than US one dollar per day. Then UN Secretary-General Kofi Annan, in 2000, enumerated worrisome statistics as follows: ${ }^{13}$

1. 1.2 billion people live with less than US $\$ 1.00$ a day

2. 800 million are malnourished

3. 153 million children are below the ideal weight

4. 115 million children are not enrolled in school with $97 \%$ of children in developing countries

5. $64 \%$ of world's illiterate population are women

6. $80 \%$ of world's refugee population are women

7. $60 \%$ of children not enrolled in primary school are female

8. Every year, 10 million children die of preventable diseases

9. Every year, 500,000 women die when giving birth or during pregnancy

In Sub Saharan Africa, 1 in 16 women die in these conditions while in OECD (Organization for Economic Cooperation and Development) countries, this same proportion is only 1 in every 2,800 women. In year 2000 alone, 22 million people died of HIV/AIDS, 13 million children lost their parents to HIV/AIDS virus, and 40 million people live with HIV/AIDS.

1. Annually, 300 million people are sick of malaria

2. Annually, 60 million people are infected with tuberculosis

3. In year 2000, 1 billion people in developing countries did not have access to drinking water

4. 2.4 billion people did not have access to sanitary services

5. $14 \%$ of the world's population in the developed world, produces $44 \%$ of the yearly CO2 total.

Kofi Annan, who was UN Secretary-General from 1997-2006, and chair of African Progress Panel, has concluded that US \$ 100 Billion are necessary to achieve the MDGs. He has said that $0.5 \%$ of GDP of developed countries is necessary for raising that amount.

The Millennium Declaration wants to reduce absolute poverty by one half, bring down mortality of children under five years old by two thirds, and mortality of mothers dying in childbirth by three fourths, by the year 2015. It is now 2020 and the expected global outcomes have not been comprehensively reached; the progress is uneven, both by developed and developing economies, rich and poor countries. The gaps between goals and

\footnotetext{
${ }^{13}$ World citizens would consider these as shameful/shameless numbers that result in a "Politics of Disgust."

(c) 2020 Josephine Maxima Acosta-Pasricha https://www.kritike.org/journal/issue 26/pasricha june2020.pdf ISSN 1908-7330
}

(c) BY-NC-ND 
key result areas are wide; the obstacles/blockages are stiff; many women and children are falling in the cracks.

Vietnam is phenomenal in that it has made all the MDGs! Ghana and Vietnam are the star performers, according to the Overseas Development Institute (ODI). Ten African countries have attained the target of halving poverty levels, ODI adds. Mwandama, Malawi presents the best prototype of a Millennium Development Village, a live document of public/private partnership, between an effective/efficient government and an empowered people with the Earth Institute of Columbia University, international organizations and philanthropic donors. But many countries lag behind, especially in women's problems. For example, the single biggest lag is in universal secondary education for young adolescent girls; because, there is no funding targeted for this. While the most lagging MDG is safe childbirth. Maternal deaths in pregnancy and childbirth, which have known scientific solutions, still hound the poorest of the poor.

Trending is the Feminization of Poverty! Extreme poverty has the face of Women and Girls. Why? How come? So, what now?

The present author believes that it is about time to evolve to Systems Thinking, from the First Order of change to the Second Order of change, from a frame-making developmental focus to a frame-breaking transformation, from the quantitative numbers game to a qualitative human side of change management and transformational leadership. ${ }^{14}$ There must be a change from the first order to the second order for the following reasons:

1. First Order Change occurs within a given Form which remains unchanged. Second Order Change is one where occurrence changes the Form itself.

2. First Order Change is change within the system. Second Order Change is change of the system.

3. First Order Change is development. Second Order Change is transformation.

The Millennium Summit has celebrated its 10th anniversary on 2022 September 2010 at the United Nations in New York. The heads of State/Government and representatives of 192 countries have attended and assessed what their leaders and countries have done in ten years and what they still have to do for the next five to ten years. Surely, these are not the same leaders who met in the Millennium Summit 2000 and signed the Millennium Declaration as a social contract. But these are new and young political leaders and millennial actionists who contribute new energy and

14 Paul Bate, Strategies for Cultural Change (Oxford: Butterworth Heinemann, 1994), 163.

(c) 2020 Josephine Maxima Acosta-Pasricha https://www.kritike.org/journal/issue 26/pasricha june2020.pdf 
technologies, a stronger political will, a higher commitment of financial and human resources. Civil society and the youth are also around to mobilize public involvement on the ground.

Then US President Barack Obama (2009-2016) has announced a New US Development Policy that will give USAid to winner countries which answer the three criteria of good governance, economic stability, and results. In other words, the "basket cases" of countries with corrupt government, instability and inefficiencies would remain in the basket. But is it enough to suggest institutional restructuring and another global action plan? Is it enough to allocate $0.7 \%$ of the gross national income of developed countries to assist developing countries in identifying barriers/blockages and motivating stakeholders? Is it enough for Poverty activists/actionists, especially students and the youth, to drum up awareness in the media and become grassroots monitors of the program?

According to Salil Shetty, director of the UN Millennium Campaign on MDGs, 23 million people around the world, mostly the youth, participated in "Stand Up" in 2007, 116 million people in "Stand Up and Speak Up" in 2008, and 179 million people in "Stand Up and Take Action" in 2009. The students and out of school youth planted ten million trees in three days. "Stand up, Take Action and Make Noise for the MDGs" happened on 17-19 September 2010 around the world; World Food Day on October 16, and World Poverty Day on 17 October 2010.

\section{UN Women}

A people's problem needs a people's solution. Women's problems need women's solutions.

On July 2, 2010, in a most historic move, the United Nations General Assembly has voted unanimously and created a new UN Entity for Gender Equality and Empowerment of Women, to be known as UN Women. This is to accelerate progress in meeting the needs of women and girls worldwide, advance human/women's rights and priorities of women, and provide a powerful unified voice of women and girls for full participation in global affairs. Gender Equality is a basic human right. Trending now, although it is not yet carved amongst the human rights, is the "human right to development." Women and girls have the human right to self-develop.

Michelle Bachelet has been appointed as the first head of UN Women, second highest in rank as undersecretary general of the United Nations on 15 September 2010. She has brought with her to the negotiating table a global network, an indomitable will power, competencies and achievements, especially in pushing the envelope wide on gender issues and women's

(c) 2020 Josephine Maxima Acosta-Pasricha https://www.kritike.org/journal/issue 26/pasricha june2020.pdf ISSN 1908-7330

(c) BY-NC-ND 
rights. As the first female president of Chile, and even in South America, she has been cutting edge success because of the following:

1. a law giving women the right to breastfeed at work

2. a law stiffening penalties for men failing payment of alimony

3. nurseries established for infants and children, domestic violence centers established for women and children

4. equal numbers of women and men serving in top government jobs, including the cabinet

5. women getting admitted for the first time to the Chilean Naval Academy

The crowning glory of her presidency, however, is "Chile Crece Contigo" 15 or "Chile Grows With You," a childhood development program seen from the lens of social investment. Her progressive policy of pragmatic socialism has reduced social inequality, extreme poverty and maternal/infant mortality and diseases, at the same time, encouraged a free market economy, public-private partnership and a global commodities boon. Her Systems Thinking emphasizes "Social Cohesion" where all members, men and women, adults and children, government and people, participate in the planning, action and development process.

It is worth reviewing her Four Main Principles, as they converge with the philosophy of Systems Thinking:

1. Human Rights: All children have the right to develop to the maximum individual potential.

2. Social Participation: The families of children participate in the initial design phase to include their needs and wants.

3. Equity: Universal action for all children of similar age.

4. Social Safety Nets: Free pre-natal and post-natal care, a mandatory paid maternal leave, State-subsidized day care centers, free childcare to working families, scholarships to adolescent mothers.

As a result, Chile has been included in the Human Development Index of UNDP as $38^{\text {th }}$ and ahead of all Latin America. Chile has also become the first South American country to be accepted into the OECD, or the Organization for Economic Cooperation and Development, composed of the world's top 31 industrialized economies.

15 See Centre for Public Impact, "Chile Creec Contigo (CCC): supporting early years development," in Centre for Public Impact: A BGC Foundation (25 May 2016), $<$ https://www.centreforpublicimpact.org/case-study/chile-crece-contigo/>.

(c) 2020 Josephine Maxima Acosta-Pasricha https://www.kritike.org/journal/issue 26/pasricha june2020.pdf ISSN 1908-7330 
"Social Justice for women and poor people," is Bachelet's lifelong call to action. Definitely, this is also evident in her present appointment as the United Nations High Commissioner for Human Rights since 1 September 2018.

\section{Global Colloquium of University Presidents}

On 4 April 2011, the Fifth Global Colloquium of University Presidents, "Empowering Women to Change the World, What Universities and the United Nations Can Do" was hosted by Dr. Amy Gutmann, president of the University of Pennsylvania.

Ban Ki-moon was keynote speaker. About 25 university presidents, accompanied by faculty experts, came from around the world. Then UN Undersecretary-General and UN Women Director Michelle Bachelet also attended and gave the keynote speech on 5 April 2011. Ban Ki-moon used Story-telling, the latest trend, as a tool for change management and transformational leadership. He opened a Johari ${ }^{16}$ window about himself. In so doing, his speech became more Leo Tolstoyan. Ban Ki-moon told the story of how in his childhood in the 1950s, he wrote to UN Secretary General Dag Hammarksjold about the status of children during the Korean war. Now that he is secretary general, he hopes that no children would need to complain in the same manner. Ban Ki-moon said, however, that there are many children around the world writing to him.

Ban Ki-moon also told the story of how the United Nations sent an all-women Indian police to Liberia for a six-month peace-keeping stint. The victims of injustice, especially of violence and sexual harassment, opened up to them. "The women felt safer and more empowered to complain about abuses," he said. But surprisingly, the Liberian women also became inspired to apply for jobs and join the police force. Ban Ki-moon has announced two heartwarming initiatives. One, is his intention to increase women workers in the United Nations. There is already egalitarianism and equal opportunity for women and men in the top management; but he is working for an increase of women to about $40 \%$ in middle management. Two, is the establishment of the UN Academic Impact for partnership between UN and the universities. "There are already 600 members from 100 countries, universities and institutions of higher education and research," he said. He wants to bridge information to policy. There is a need for research in gender equality and women empowerment, especially in data gathering, analysis and

\footnotetext{
${ }^{16}$ Johari window is a tool in Psychology where a person reveals something about himself, and the other person that he is in conversation with is encouraged to reveal a something similar. It is considered rude not to reciprocate.

(c) 2020 Josephine Maxima Acosta-Pasricha https://www.kritike.org/journal/issue 26/pasricha june2020.pdf ISSN 1908-7330
}

(c) BY-NC-ND 
management, concepts, definitions, methods and tools for organization, change management and transformative leadership.

Meanwhile, in her keynote speech to the university presidents and faculty experts in the workshop, Bachelet posited her Vision Statement for UN Women: For women and girls, men and boys to have equal opportunities and capabilities; for gender equality and empowerment of women; for human rights, peace and security. Bachelet has enumerated Five Thematic Priorities as follows:

1. women leadership and participation

2. ending violence in women and girls

3. engaging women in peace building processes

4. enhancing women's economic empowerment

5. gender equality central to national development planning

Bachelet has also put forth Four Proposals:

1. collaboration between interested faculty with UN women senior policy advisor to contribute to UN Women's research agenda

2. UN Women Fellow's Programme, a network of engaged professionals

3. UN Women Internship Programme for master's degree students

4. Global Strategy for Women's and Children's Health

When I personally met Bachelet after the conference, I told her that I have sent her a research paper on "Teaching/Learning Gender and Sex Through Systems Thinking in Asian and African Philosophy." Bachelet asked me "When?" I said, two days ago. Bachelet said that she has just flown in from Nairobi to Philadelphia, and she has not gone through her emails. She promised to read the paper. I have never met a president, or former president, or diplomat who is so pointed, specific and concrete even in her casual conversation. Bachelet is "so in the moment."

Indeed, women workers are most necessary now in post-disaster and post-conflict situations in Japan, Africa, and the Middle East. Trending is Feminization of global disaster. Women and children, infants without milk in Japan, is the Face of the triple tragedy of earthquake, tsunami, and nuclear radioactivity. Women journalists in the Middle East, being stroked on the hair and being told with a soothing voice, in a foreign language: "You will die tonight," is also the face of violence, rape, sexual harassment. In India, women and girls are raped; one rape reported every 15 minutes, the worst instance of which is Nirbhaya, who was gang raped by 6 men and a long pipe inserted into her reproductive organ. Gender Justice is rendered only after four of the 


\section{SYSTEMS THINKING, GENDER, AND SEX}

six rapists were hanged to death on 20 March 2020, 7 years after the heinous crime was committed on 16 December 2012.

Why? How could all these happen? What now?

UN Women, with an expected budget of US \$500 Million, has started to be operationalized in January 2011.

In 2008, the World Bank says that the cost of achieving MDG 3 is about US $\$ 60$ Billion to US $\$ 80$ Billion. Spain and the Scandinavian countries are first to contribute to this Global Fund for Women. UN Women has double the combined funds and human resources of four agencies. It merges four existing gender entities into one powerful dynamic organization. The four programs or agencies are:

1. Office of Special Adviser on Gender Issues and Advancement of Women (OSAGI, 1997)

2. UN International Research and Training Institute for Advancement of Women (UN-INSTRAW, 1976)

3. UN Development Fund for Women (UNIFEM, 1976, the largest of four)

4. Division for Advancement of Women (DAW, set up in 1946)

The question to ask is: with the MDGs having ended in 2015 and having become just one part of the 17 SDGs, as Goal 5 or Gender Equality, can the UN Women focus on de-Feminization of Poverty?

The MDGS have been phased out in 2015; its data frozen in contemporary history can no longer be scaled up or updated. The MDGs most probably will be the most successful anti-poverty movement in history. ${ }^{17}$ The SDGs, "the blueprint to achieve better and sustainable future for all," are the focus of the United Nations until 2030. The present author believes that the success of the MDGs cannot be duplicated even by the SDGs, especially with the Corona Virus pandemic causing humanitarian havoc of more than 4 million global case infections, and deaths of about 300,000 in 177 countries. There is unemployment of 20 million workers in the United States alone. The Stock Market is down, factories are shutting down, companies are declaring bankruptcies. Jobs, housing, education, health, food supply are all put at unprecedented risk.

Women and children and the minorities are the first to suffer. Women and children will not be first and prior in Stimulus Package Aid. Again, there will be Feminization of Poverty!

17 Francyne Harrigan and Sharon Birch, "MDGs produced most successful antipoverty movement in history: UN report," United Nations Development Programme (6 July 2015), $<$ https://www.undp.org/content/undp/en/home/news-centre/news/2015/07/06/mdg-sproduced-most-successful-anti-poverty-movement-in-history-un-report.html $>$.

(c) 2020 Josephine Maxima Acosta-Pasricha https://www.kritike.org/journal/issue 26/pasricha june2020.pdf ISSN 1908-7330

(c) BY-NC-ND 


\section{Recommendations}

This paper would like to recommend three Breakthrough Action Plans to be done in academia and institutions on available research grants, with great innovation and creativity:

1. Perhaps, there is a need to bridge the gap between the Millennium Development Goals that evolved to be just Goal 5 called Gender Equality of the Sustainable Development Goals, and an Idealized Design through Systems Thinking as innovated by Russell Ackoff, but with a focus on the women's perspective.

2. Language is also a means of dealing with problems in the world. Perhaps, through "Communicative Action" or communicating through action as taught by Jurgen Habermas, we can increase understanding and learning, innovation and creativity, mutuality and respect to attain peace, truth and justice. This can be done within the context of universal education in "Deliberative Democracy" or Discourse Democracy as taught by Habermas, John Rawls and Amy Gutmann.

3. The "Theory of Capabilities" applied in economics by Nobel Laureate Amartya Sen, and in philosophy by Martha Nussbaum, may extend insights through Gender Analysis into better quality of life assessments in development/transformational economics and international/national policymaking. Nussbaum has written "Women and Human Development," a framework-breaking seminal work, on women's issues, questions and problems.

Gender Economics is the way to go forward especially in a postpandemic crisis situation. ${ }^{18}$ Gender Economics needs to be seen through Systems Thinking lens or Systems Thinking Zeitgeist.

Independent Researcher, Delhi, India and Manila, Phlippines

18 On 12 May 2020, Indian Prime Minister Narendra Modi delivered a state of the nation address in response to the Covid19 crisis situation. He enumerates five pillars as basis of an action plan. These are economy, infrastructure, technology-based systems, democracy and demand. Note that Systems Thinking is in operation. His mantra is "Aatmanirbhar Bharat Abhiyan" or a Self-Reliant India.

(c) 2020 Josephine Maxima Acosta-Pasricha

https://www.kritike.org/journal/issue 26/pasricha june2020.pdf

ISSN 1908-7330 


\section{SYSTEMS THINKING, GENDER, AND SEX}

\section{References}

Acosta-Pasricha, Josephine, "Teaching/Learning Gender and Sex Through Systems Thinking in Asia and Africa" (paper presented at the Rio+20: United Nations Conference on Sustainable Development, Rio de Janeiro, Brazil, 20-22 June 2012).

Ackoff, Russell, "Towards a System of Systems Concept," in Management Science, 17:11 (July 1971), 662. See also Russell Ackoff, "Systems Thinking Speech by Dr. Russell Ackoff," Awal Street Journal in YouTube (1 November 2015), <https://www.youtube.com/ watch? $\mathrm{v}=$ EbLh7rZ3rhU>.

Ackoff, Russell, Herbert J. Addison, and Sally Bibb, A Little Book of f-Laws: 13 Common Sins of Management (Devon, UK: Triarchy Press, 2006).

Bate, Paul, Strategies for Cultural Change (Oxford: Butterworth Heinemann, 1994).

Cavanaugh, Michael, "Coaching from a Systemic Perspective: A Complex Adaptive Conversation," in Evidence Based Coaching Handbook: Putting Best Practices to Work for your Clients, ed. by Dianne R. Stober and Anthony M. Grant (New Jersey: John Wiley \& Sons, 2006).

Centre for Public Impact, "Chile Creec Contigo (CCC): supporting early years development," in Centre for Public Impact: A BGC Foundation (25 May 2016), <https://www.centreforpublicimpact.org/case-study/chilecrece-contigo/>.

Conner, Daryl, Leading at the Edge of Chaos: How to Create the Nimble Organization (New York: John Wiley \& Sons, 1998), 22.

Harrigan, Francyne and Sharon Birch, "MDGs produced most successful anti-poverty movement in history: UN report," United Nations Development Programme (6 July 2015), <https://www.undp.org/ content/undp/en/home/news-centre/news/2015/07/06/mdg-sproduced-most-successful-anti-poverty-movement-in-history-unreport.html>.

McNamara, Robert S., "Address to the Board of Governors," (address delivered to the Board of Governors of the World Bank at the Annual General Meeting, Nairobi, Kenya, 24 September 1973), $<$ http://documents1.worldbank.org/curated/en/930801468315304694/ pdf/Address-to-the-Board-of-Governors-by-Robert-SMcNamara.pdf $>$.

"Purchasing Power Parity 2005," in World Health Organization, $<$ https://www.who.int/choice/costs/ppp/en/>.

Silverman, Lori L., Wake Me Up When the Data is Over: How Organizations Use Stories to Drive Results (USA: John Wiley \& Sons, 2006).

(c) 2020 Josephine Maxima Acosta-Pasricha https://www.kritike.org/journal/issue 26/pasricha june2020.pdf ISSN 1908-7330

(c) BY-NC-ND 
United Nations, "Ban calls for efforts to secure equal rights for LGBT community," in United Nations Sustainable Development Goals (21 September 2016), <https://www.un.org/sustainabledevelopment/ blog/2016/09/ban-calls-for-efforts-to-secure-equal-rights-for-lgbtcommunity/>.

"General Strategy for Women's and Children's Health," in Every Woman and Child, <http://www.everywomaneverychild.org/images/ content/files/global strategy/full/20100914 gswch en.pdf $>$. 